\title{
SIDEBAR
}

\section{A Memory of Ice \\ THE ANTARCTIC VOYAGE OF THE GLOMAR CHALLENGER}

Book by Elizabeth Truswell

Reviewed by Peter N. Webb and Peter J. Barrett

Deep Sea Drilling Project (DSDP) Leg 28 initiated a new era of seafloor exploration when Glomar Challenger departed Fremantle (West Australia) for a 69-day expedition from late December to February in the austral summer of 1972-73. Along with Elizabeth (Liz) Truswell, the author of $A$ Memory of Ice: The Antarctic Voyage of the Glomar Challenger, we were members of the shipboard science party, and we value the opportunity to relive this pioneering Antarctic expedition through her account. Not every ocean drilling leg is fortunate enough to have its shipboard and science activities documented in such an interesting, permanent, and colorful fashion, and we feel privileged to have the opportunity here to share a few memories from that spring that surfaced while reading $A$ Memory of Ice.

Liz Truswell skillfully interleaves diary-based personal recollections of deep ocean drillship science from five decades ago, the significant events in polar exploration and science of the preceding two centuries, and the more significant south polar Earth science achievements in the time since 1973. As the reader journeys through $A$ Memory of Ice, the author discusses a wide spectrum of science topics, with particular attention devoted to her career-long research emphases in paleobotany, palynology, and plant biogeography. The use of high-quality illustrations, many reproduced from archival sources, strengthens the impact of the text. A bibliography and a glossary of terms are also provided.

Why has almost a half-century elapsed before the telling of this expedition's events, its scientific results, and the thoughts surrounding its place in science history? A pre-syn-post approach that spans a few decades allows a much more valuable understanding of how science evolves and progresses. This makes Liz Truswell's presentation a meaningful source for aspiring Earth scientists and perhaps even some experienced researchers. Published expedition accounts from the heroic-era expeditions by Scott, Shackleton, Amundsen, Mawson, and others were usually published shortly after an expedition, emphasizing exploration and the associated suffering and hardships and offering relatively little in the way of scientific information. This latter publication style satisfied the immediate needs of a curious public and the generous expedition sponsors.

The scientific objectives of DSDP Leg 28 were rooted in forging a better understanding of the high-latitude Cenozoic sedimentary record. Let us briefly recall the status of Antarctic
Cenozoic Earth science before the arrival of Leg 28 aboard Glomar Challenger. Prior to 1972, the Cenozoic geology of Antarctica was very poorly known. Cenozoic sediments and fossils had been documented at the northern end of the Antarctic Peninsula-West Antarctica-in the early twentieth century. The record in East Antarctica was confined to surficial Quaternary terrestrial glacial deposits along the Ross SeaTransantarctic Mountains margins together with volcanic rocks, some of which are now known to be late Cenozoic in age. Cenozoic geology was not a primary program during the 1957-1959 International Geophysical Year (IGY) activities in West and East Antarctica. In one of the earlier reviews of Antarctic geology, Harrington (1965) noted: "There is as yet no sedimentary record of the history of East Antarctica from the later Jurassic to the Pliocene." Cenozoic data from the Antarctic continental shelves and floors of the circum-Antarctic deep ocean were equally absent. In the late 1960s, the association of terrestrial glacial and fjordal marine deposits and volcanic extrusions in the Dry Valleys (now McMurdo Dry Valleys) adjacent to the Ross Sea provided the first concrete evidence that glaciation in the Transantarctic Mountains predated the Quaternary and might span the late Miocene and Pliocene.

Prior to the availability of direct evidence derived from sources in Antarctica, biogeographers, paleontologists, stratigraphers, sedimentologists, and isotope geochemists, among others, working in lower latitude locales, searched for environmental indicators of widely oscillating polar, temperate, and tropical paleoclimate across Southern Hemisphere latitudes in the past. In 1953 and 1962, C.A. Fleming explored the possible impact Late Cenozoic expansion of cool glacialinterglacial water-mass circulation of Antarctic origin had on marine biota, basin histories, and stratigraphy in New Zealand. In 1963, Fleming proposed that Antarctic and subantarctic climate change drove alpine vegetation zones further north and treeline elevations to higher altitudes (including that of the southern beech genus Nothofagus) in New Zealand and in the Southwest Pacific. These thoughtful speculations were subtle hints to later investigators that there were indeed paleoclimatically important linkages between the cryogenic terrestrial and marine Antarctic Cenozoic and coeval records in temperate latitudes to the north.

As Glomar Challenger recovered Cenozoic biogenic and clastic sedimentary successions from six drillholes in the Southern Ocean and four in the Ross Sea, it was instantly 
apparent to the paleontology group that we had entered a distinctly different paleo-biological world from that we were accustomed to back home, way to the north. The highresolution pelagic and benthic biostratigraphic zonations of New Zealand and Australia could not be applied in these extreme southern high latitudes. The paleontologists of Leg 28 made the first attempts to develop austral biostratigraphic zonations that were based principally on diatoms but that also included other microfossil groups such as foraminifera and radiolaria and the occasional temperate zone invaders from the north. These efforts continue today. Our preliminary time controls proved adequate for contributing to the principal expedition objectives.

The scientific and technical successes of DSDP Leg 28 were many. We quote a few of them directly from Liz's account.

The 69 days at sea that we had enjoyed-or endured, depending on one's experience and point of view-had produced results that were outstanding for the time. Our mandate, when we left Fremantle in December 1972, had been to explore the history of the Antarctic icecap and the high-latitude circulation of the seas surrounding that continent; and to investigate the timing and nature of sea-floor spreading between Australia and Antarctica... Overall, the most demanding of aims was to test the feasibility of drilling the sea floor in high southern latitudes under the constant threat of icebergs and the storms that characterise those regions... By all measures, the voyage had been a success. We had succeeded in pushing back the age of the icecap from the 3-5 million years that was accepted when we left port, to something close to 26 million years... We had tested the age and rates of sea-floor spreading across the Southeast Indian Ridge separating Antarctica and Australia, using ages from tiny fossils in the sediments lying atop the volcanic basement of the sea floor. We confirmed that these were in accord with magnetic ages deduced from earlier seismic mapping... More recent reviews of the whole program of drilling the sea floor of the deep oceans, reviews that can now look back over 50 years, classify the Deep Sea Drilling Project (DSDP), and its rugged Glomar Challenger, as belonging to an initial phase of 'curiosity driven' exploration-a rather simplified 'looking to see what's there' approach. In contrast, according to these reviews, more recent phases have singled out particular issues in Earth science and have sought answers to global problems through focusing on carefully selected drilling programs. Perhaps that is so in general, but the history of the polar ice sheet, an issue to which several DSDP expeditions contributed substantially, is a subject of ongoing scientific concern at a global level.

Successes emanating from DSDP Leg 28 spurred the launching of a number of highly technical deep stratigraphic drilling programs over the last half century, all aimed at sampling and deciphering the Antarctic Cenozoic cryogenic record. These projects include: Dry Valley Drilling Project (DVDP), McMurdo Sound Sediment and Tectonic Studies (MSSTS), Cenozoic Investigations in the Ross Sea (CIROS), Ross Ice Shelf Project (RISP), Cape Roberts Project (CRP), and ANtarctic DRILLing Project (ANDRILL). All of these programs were international initiatives to some degree. Examination of Leg 28 drill core has continued through the decades and is still being incorporated in research activities today. Countless graduate students prepared theses and dissertations based on Leg 28 core from the Southern Ocean and Ross Sea. Many proceeded on to careers in academia and industry. Some continued to contribute to the Antarctic Earth sciences, often becoming lead investigators of the drilling initiatives noted above.

We conclude by quoting a few lines by Liz Truswell from the prologue of Memory of Ice:

The book gives my personal story-that of a young scientist feeling largely unprepared-thrown into the excitement and absorbing interest of field work in one of the most remote regions of the globe... This is a world full of stories. Many have been told before, but fresh details continue to emerge. There are stories of human endurance in encounters with the elements, of competing national and individual ambitions, of dealing with the novel and unexpected in nature and of persistence in the everyday tasks of mapping and recording. It has often proved difficult to separate these different threads that are interwoven with the story of Leg 28.

The often deeply personal recollections that are so central to the success of this account will reverberate with many readers, especially those who have had like experiences in the remotest parts of Earth. This is a truly scholarly contribution and likely to figure prominently in future research by polar historians. The legacy of DSDP Leg 28 is certainly secure.

\section{REFERENCES}

Fleming C.A. 1953. The Geology of the Wanganui Subdivision. New Zealand Geological Survey Bulletin, new series number 52, Department of Scientific and Industrial Research, Wellington, New Zealand, $361 \mathrm{pp}$.

Fleming C.A. 1962. New Zealand biogeography: A paleontologist's approach. Tuatara 10(2):53-108.

Fleming C.A. 1963. Age of the alpine biota. Proceedings of the New Zealand Ecological Society 10:15-18.

Harrington, H.J. 1965. Geology and morphology of Antarctica. Pp. 1-71 in Biogeography and Ecology in Antarctica. J. van Mieghan and P. van Oye, eds, Springer, Dordrecht, the Netherlands.

\section{BOOK INFO}

A Memory of Ice: The Antarctic Voyage of the Glomar Challenger by E. Truswell. The Australian National University Press, 2019, 246 pages, free formats available for download, print version available for purchase, https://doi.org/10.22459/MI.2019.

\section{REVIEWERS}

Peter N. Webb (peternoelwebb@yahoo.com) is Professor Emeritus, School of Earth Sciences, The Ohio State University, Columbus, OH, USA. Peter J. Barrett (peter.barrett@vuw.ac.nz) is Professor Emeritus, Antarctic Research Centre, Victoria University of Wellington, New Zealand. 